\title{
A Pioneer from India in Research on Quality of Life, Human Wellbeing and Social Indicators of Development
}

\author{
Krishna Basu Mazumdar ${ }^{1}$
}

Published online: 21 April 2017

(C) Springer Science+Business Media Dordrecht and The International Society for Quality-of-Life Studies (ISQOLS) 2017

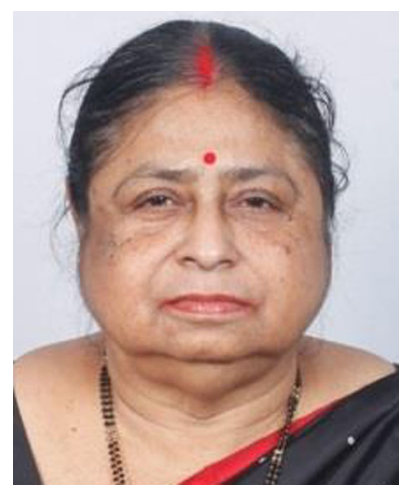

In 1948, immediately after the partition of Bengal (the then part of undivided India), my family had to leave East Pakistan or East Bengal and migrated to West Bengal, (i.e. part of divided India). They had to leave behind all of their movable as well as immovable properties, i.e. farm lands, orchards, household properties, domestic animals, pets, clothing, utensils etc. They had to leave their professions/earnings and leap into the dark - in a complete and uncertain condition. They migrated to India as refugees only with their lives and only to save their lives. In fact, within a day they became almost beggars. From the very next morning, they began their struggle for life in an unknown country, without any capital and with no help.

I was born in early 1949, when the entire family was struggling for existence. Consequently, from the very first day of my life, I had to suffer from poverty in all aspects of human life. At the age of three, I was admitted to the LA Martenere for Girls'

Krishna Basu Mazumdar

krishnamazumdar@ymail.com

1 Indian Statistical Institute, Kolkata, West Bengal 700108, India 
School. But due to poverty, my family had to move about $20 \mathrm{~km}$ away from the capital city of Calcutta to a remote village in the district of North 24 Parganas. The place lacked safe drinking water, had no electricity, medical facilities, and adequate schools and was poorly connected. The nearest good school was about three to four kilometres away. I was admitted to that Christian Missionary School, named 'Dum Dum Christ Church Girls' High School'. The school was well disciplined in all respects: there was a very strict dress code and attendance policy, text books and other study materials. Students were used to being punished and routinely disciplined for breaking any kind of rule. I lacked proper school uniform and study materials including text books. But, I was never punished for such offences, as I used to score the highest in all subjects, including Bible and crafts. I passed the school leaving (Higher Secondary) in 1968 with high First division from this school.

I graduated from the University of Calcutta (Lady Brabourne College) with Honours with a major in Economics and a minor in Mathematics. In 1974, I obtained a Masters in Economics, specializing in Statistics, Econometrics and Mathematical Economics. In this context, I must confess that if I did not receive free studentship ${ }^{1}$ for my graduate and post graduate studies, I would not have been able to continue my studies after graduating from high school.

In 1975, I received prestigious University Grants Commission's Research Fellowship for the next four years to support the completion and submission of my Ph.D. thesis. I worked for my Ph.D. dissertation at the University of Calcutta (Department of Economics) under the supervision of Professor Vatsala Mukherji. The topic of the thesis was "Intersectoral Analysis of a Developing Economy". The thesis was submitted in 1980. The University received favorable comments on the thesis from Professor D.W. Jorgenson of the Harvard University and Professor R.N. Bharawdaj of the Gokhale Institute of Economics and Politics. I was awarded my Ph.D. in Economics from Calcutta University in late 1980.

After submitting my Ph.D. dissertation in 1980, I joined Indian Statistical Institute. This brought me the opportunity of independent studies. Sufferings during my childhood and throughout my student life taught me that the quality of life of human beings does not depend on the availability of basic needs, like food. Consequently, as soon as I began to undertake independent research, I started identifying other aspects of human life that makes life good.

These led me to think about alternative measures of a country's standard of living, other than the more typical economic indicators like per capita gross domestic product, income and education levels. I was inspired by the publications of Irma Adelman, Paul Streeten and other pioneers in this field. Through my work, I determined a new set of indicators and published my first paper in this strand in 1988. Later I proceeded to include more dimensions of human well-being. My studies in this field include formation of different types of composite indices, testing of causality between economic development and social development, pair-wise comparisons of countries on the basis of socio-economic aspects of human life, testing of increasing or decreasing

\footnotetext{
${ }^{1}$ Selected References

Mazumdar, K. (2003). A new approach to human development index. Review of Social Economy, 61(4), $535-549$.

Majumder, K. (2002). A note on cross country convergence in standard of living. Applied Economics, 9(2), $87-90$.
} 
inequalities among countries in different aspects of socio-economic-environmental indicators of development and human well-being. Major features of my studies in the area of human well-being/quality of life/social indicators of development are use of secondary sources of data, application of different Econometric methods, Statistical tools and Mathematical tools and Economic theories.

Apart from my studies in the field of Quality of Life / Human Well-being / Social Indicators, I worked in the areas of Urbanization, Wet Lands, Services Sector in Developing Countries, Regional Variations in Purchasing Power etc. My academic activities include five published books, more than fifty published or mimeographed papers, presentation of papers at many national and international conferences and seminars at different Universities and Institutes, acted as a reviewer of many papers for different journals and conducted many research projects. 